\title{
Road Accidental Analysis: A Case Study of Rajasthan State, India
}

\author{
Dr. Sabiha Khan ${ }^{1}$, Prof. I. M. Kayamkhani ${ }^{2}$ \\ ${ }^{1}$ (Department of Geography, M.L.S.University, Udaipur, India) \\ ${ }^{2}$ (Department of Geography, M.L.S.University, Udaipur, India)
}

\begin{abstract}
Today, according to the World Health Organization (WHO), motor vehicle crashes kill about 1.2 million people each year. That is set to rise to 2 million by 2020 unless new safety measures are taken, making road traffic injuries the third largest cause of death and disability. The present paper reviews on the road accidental analysis in the state of Rajasthan, India. In order to appreciate the scale of the problem in the state, it is common practice to relate the number of road accidents and deaths to demographic and vehicles in districts (administrative unit of a state) of Rajasthan.
\end{abstract}

Keywords: Deaths, Fatality Rate, Fatality Risk, Road Accidents, Severity Index

\section{Introduction}

Nearly 1.3 million people die every year on the world's roads, and up to 50 million are injured.[1] Traffic fatalities measured by the proxy of motor vehicle registrations and population, increasing traffic volume leads to an increase in fatalities per capita .[2][3] In India, the motor vehicle population is growing at a faster rate than the economic and population growth. The road network facing the problem of road accidents with the expansion in motorisation. [4] Various studies already have been done to linking road traffic fatalities with vehicle ownership, regional population and economic growth. [5][6][7][8][9]This paper discusses the use of data of road accidents to evaluate the effectiveness of countermeasures and to compare the safety of different districts of Rajasthan state in different periods of time.[10][11] during this period risk factors in different districts have been compared[12] It is observed that few works have been carried out on statistical analysis of accidents particularly on two-lane National Highways. Various indices to measure fatalities also have been applied on National Highways of the state. [13][14][15]. Secondary data of population, registered vehicles and road accidents have been obtained from various government departments of India. [16][17][18]

Rajasthan state is one of the most attractive destinations in India and has a prominent place on the tourist map of the world. Rajasthan is the largest state in the country in terms of geographical area, which constitutes 10.41 per cent area of the country and 5.67 per cent of national population (census 2011). Healthy transport system is an indicator of economic health and development of a state. As on $31^{\text {st }}$ March, 2012 , the total length in the state is expected to be 190402 Kms. The road density in the state is expected to be $55.63 \mathrm{~km}$ per 100 sq. km. share of registered vehicles in state is $5.65 \%$ of total of the India.

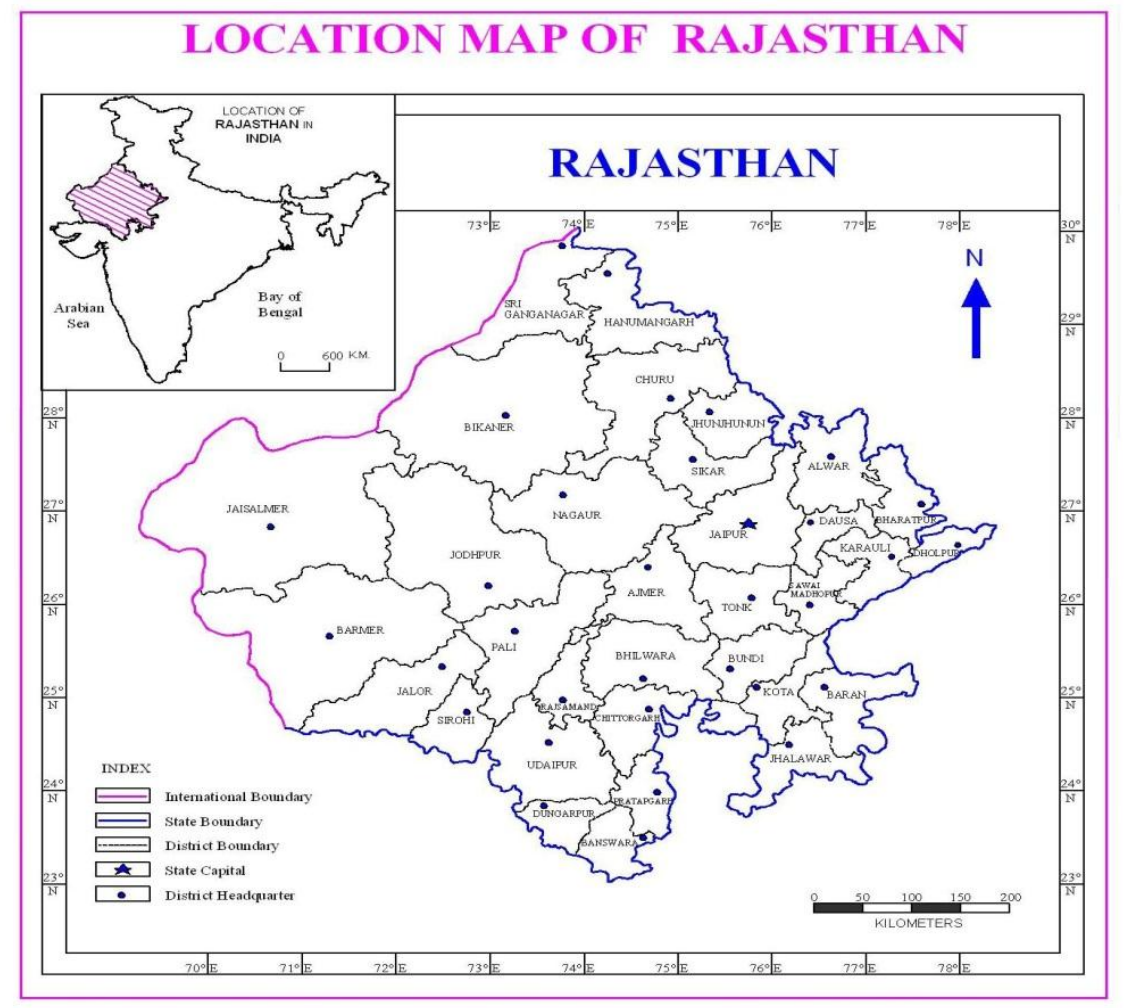




\section{Result And Discussion}

Traffic accidents are major problem both in developed and developing countries. Road accident is becoming more and more common in today's society and contributes to a significant number of deaths as the result. Current traffic safety conditions in India are extremely serious. According to National Crime Record Bureau total incidences of accidental deaths due to natural and un-natural causes increased 1.4 times, while no. of deaths due to road accidents increased 1.7 times from 2001 to 2011. The share of road accidental deaths has increased from $29.61 \%$ in 2001 to $35.01 \%$ in 2011 (Fig.1).

Table 1: Incidence of Accidental Deaths by Natural and Un-Natural Causes in India

\begin{tabular}{|c|c|c|c|c|c|c|}
\hline \multirow[t]{2}{*}{ Year } & \multirow{2}{*}{$\begin{array}{l}\text { Natural } \\
\text { Causes } \\
\text { (A) }\end{array}$} & \multicolumn{3}{|c|}{ Un-Natural Causes } & \multirow{2}{*}{$\begin{array}{l}\text { Total } \\
(\mathrm{A}+\mathrm{B})\end{array}$} & \multirow{2}{*}{$\begin{array}{l}\text { Share of Road } \\
\text { Accidents in } \\
\text { Total Incidences }\end{array}$} \\
\hline & & $\begin{array}{l}\text { Other Un- } \\
\text { Natural }\end{array}$ & $\begin{array}{l}\text { Road } \\
\text { Accidents }\end{array}$ & $\begin{array}{c}\text { Total Un- Natural } \\
\text { (B) }\end{array}$ & & \\
\hline 2001 & 36651 & 154106 & 80262 & 234368 & 271019 & $29.61 \%$ \\
\hline 2011 & 23690 & 230360 & 136834 & 367194 & 390884 & $35.01 \%$ \\
\hline
\end{tabular}

Source: National Crime Record Bureau, Govt. of India

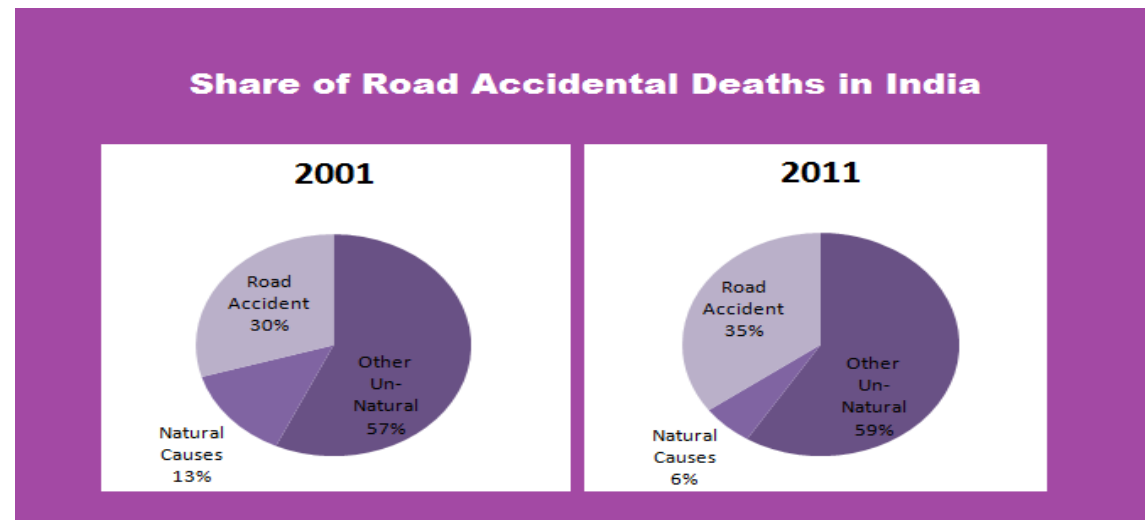

Figure 1: Share of Road Accidental Deaths in India (2001 and 2011)

Table 2: Decadal Growth of Population and Registered Vehicles

\begin{tabular}{|c|c|c|c|c|c|c|}
\hline \multirow[t]{2}{*}{$\begin{array}{l}\text { Country } \\
\text { /State }\end{array}$} & \multicolumn{2}{|c|}{$\begin{array}{l}\text { Population } \\
\text { (in millions) }\end{array}$} & \multirow[t]{2}{*}{$\begin{array}{l}\text { Decadal } \\
\text { growth }\end{array}$} & \multicolumn{2}{|c|}{$\begin{array}{l}\text { Registered vehicles } \\
\text { (in thousands) }\end{array}$} & \multirow[t]{2}{*}{$\begin{array}{c}\text { Decadal } \\
\text { growth }\end{array}$} \\
\hline & 2001 & 2011 & & 2001 & 2011 & \\
\hline India & 1028.61 & 1210.19 & $17.64 \%$ & 54991 & 114953 & $109.03 \%$ \\
\hline Rajasthan & 5.65 & 6.85 & $21.31 \%$ & 2943 & 6490 & $120.52 \%$ \\
\hline
\end{tabular}

Source: Census, Govt. of India

Rapid growth of population coupled with increased economic activities has favoured in tremendous growth of motor vehicles. From 2001 to 2011 growth of population in India is $17.64 \%$, while it is $21.31 \%$ in Rajasthan. Population increased 1.2 times, which is equal both in India and Rajasthan, while there has been more than two fold increase in number of registered vehicles. It means number of vehicles per person is increased (Table 2).

Table 3 displays number of road accidents and number of deaths occurred in India and Rajasthan during these years. Growth of road accidental cases is $35.96 \%$ in India, while it is $16.23 \%$ in Rajasthan. Decadal growth in number of deaths due to road accident is very high both in India and Rajasthan, which is $70.48 \%$ and $77.98 \%$ respectively.

Table 3: Decadal Growth in Number of Road Accidents and Deaths

\begin{tabular}{|c|c|c|c|c|c|c|}
\hline \multirow{2}{*}{$\begin{array}{l}\text { Country } \\
\text { /State }\end{array}$} & \multicolumn{2}{|c|}{ No. of cases of road accidents } & \multirow{2}{*}{$\begin{array}{l}\text { Decadal } \\
\text { growth }\end{array}$} & \multicolumn{2}{|c|}{ No. of deaths due to road accident } & \multirow{2}{*}{$\begin{array}{l}\begin{array}{l}\text { Decadal } \\
\text { growth }\end{array}\end{array}$} \\
\hline & 2001 & 2011 & & 2001 & 2011 & \\
\hline India & 323720 & 440123 & $35.96 \%$ & 80262 & 136834 & $70.48 \%$ \\
\hline Rajasthan & 19999 & 23245 & $16.23 \%$ & 5187 & 9232 & $77.98 \%$ \\
\hline
\end{tabular}

Source: National Crime Record Bureau, Govt of India 


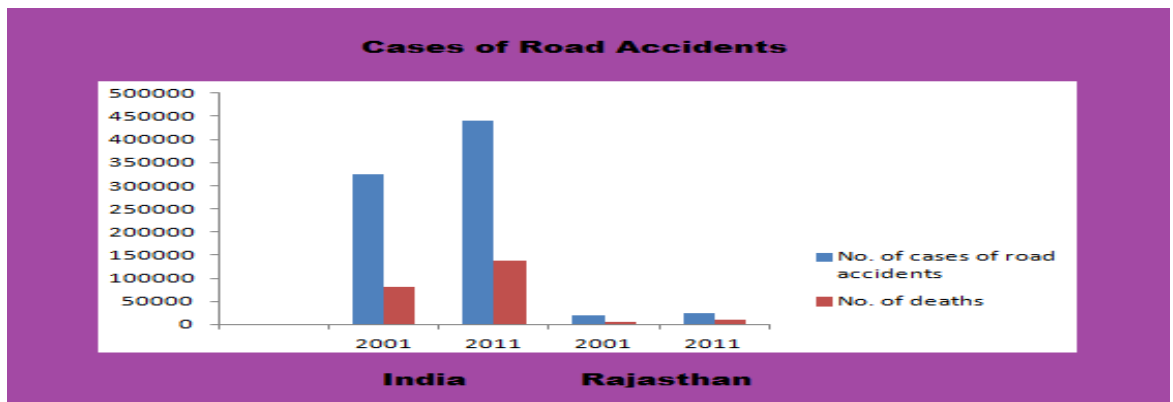

Figure 2: No. of Road Accidents and No. of Deaths due to Road Accidents during these years

Fig. 2 shows that the decadal growth in number of road accidental cases in India is higher than in Rajasthan. But decadal growth in number of deaths due to road accidents in India is lower than in Rajasthan, which shows greater severity in Rajasthan.

The accident severity index measures the number of deaths per 100 road accidents. From 2001 to2011 it increased 1.25 times in India, while 1.5 times in Rajasthan. Fatality risk is defined as number of deaths per $1,00,000$ population. During this decade it increased 1.5 times both in India and Rajasthan. Fatality rate is defined as number of deaths per 1,000 vehicles, which decreased in this decade (Table 4). These formulas were used for estimating road accidents in districts of Rajasthan

Table 4: Analysis of Road Accidents through various Indices

\begin{tabular}{|l|l|l|l|l|l|l|}
\hline \multirow{2}{*}{$\begin{array}{l}\text { Country } \\
\text { S State }\end{array}$} & Severity Index & Fatality Risk & Fatality Rate \\
\cline { 2 - 7 } & 2001 & 2011 & 2001 & 2011 & 2001 & 2011 \\
\hline India & 24.79 & 31.09 & 7.80 & 11.31 & 1.46 & 1.19 \\
\hline Rajasthan & 25.94 & 39.72 & 9.18 & 13.47 & 1.76 & 1.42 \\
\hline
\end{tabular}

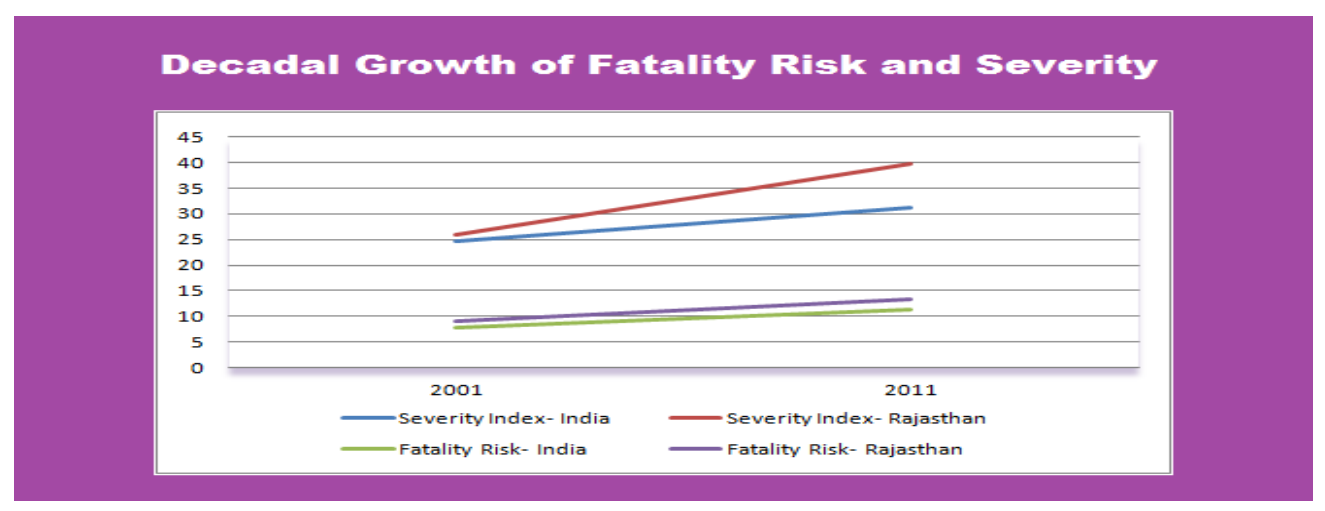

Figure 3: Severity Index and Fatality Risk in India and Rajasthan

It can be seen in Fig.3 that severity index, fatality rate and fatality risk of India and Rajasthan have been increased and the value of these indices is higher in Rajasthan than in India.

The Rajasthan has thirty three districts, which are administrative units of a state. Population of 2011 and number of registered vehicles of 2012 of various districts are obtained from Census, Govt. of Rajasthan and Department of Transport, Govt. of Rajasthan respectively. Districts have been classified in various categories according to their obtained values of fatality risk and fatality rate (Table 5).

Table 5: Fatality Risk and Fatality Rate in Different Districts of Rajasthan

\begin{tabular}{|l|l|l|l|l|l|}
\hline S.No. & District & $\begin{array}{l}\text { Population } \\
(2011)\end{array}$ & $\begin{array}{l}\text { Fatality Risk } \\
(2011)\end{array}$ & $\begin{array}{l}\text { Vehicles } \\
\text { registered(2012) } \\
\text { Rate } \\
(2012)\end{array}$ \\
\hline 1. & Ajmer & 2583052 & 20.05 & 581133 & 1.00 \\
\hline 2. & Alwar & 3674179 & 14.29 & 476038 & 1.15 \\
\hline 3. & Banswara & 1797485 & 9.40 & 184618 & 0.86 \\
\hline 4. & Baran & 1222755 & 10.96 & 191008 & 0.78 \\
\hline 5. & Barmer & 2603751 & 10.06 & 139361 & 1.85 \\
\hline 6. & Bharatpur & 2548462 & 11.18 & 269116 & 1.02 \\
\hline 7. & Bhilwara & 2408523 & 14.08 & 414977 & 0.85 \\
\hline 8. & Bikaner & 2363937 & 13.58 & 319845 & 1.13 \\
\hline 9. & Bundi & 1110906 & 14.04 & 150748 & 0.98 \\
\hline
\end{tabular}


Road Accidental Analysis: A Case Study of Rajasthan State, India

\begin{tabular}{|c|c|c|c|c|c|}
\hline 10. & Chittorgarh & 1544338 & 14.18 & 278492 & 0.90 \\
\hline 11. & Churu & 2039547 & 11.62 & 106652 & 2.71 \\
\hline 12. & Dausa & 1634409 & 19.76 & 143618 & 1.80 \\
\hline 13. & Dholpur & 1206516 & 11.44 & 87671 & 1.79 \\
\hline 14. & Dungarpur & 1388552 & 9.58 & 130118 & 1.21 \\
\hline 15. & Ganganagar & 1969168 & 10.82 & 330149 & 0.61 \\
\hline 16. & Hanumangarh & 1774692 & 11.27 & 134694 & 1.10 \\
\hline 17. & Jaipur & 6626178 & 19.65 & 1999625 & 0.61 \\
\hline 18. & Jaisalmer & 669919 & 10.45 & 42706 & 1.97 \\
\hline 19. & Jalore & 1828730 & 6.99 & 124378 & 1.23 \\
\hline 20. & Jhalawar & 1411129 & 8.36 & 150070 & 1.0 \\
\hline 21. & Jhunjhunu & 2137045 & 10.90 & 180274 & 1.31 \\
\hline 22. & Jodhpur & 3687165 & 14.16 & 771244 & 0.79 \\
\hline 23. & Karauli & 1458248 & 8.16 & 78701 & 1.75 \\
\hline 24. & Kota & 1951014 & 11.89 & 542768 & 0.39 \\
\hline 25. & Nagaur & 3307743 & 10.94 & 275303 & 1.20 \\
\hline 26. & Pali & 2037573 & 15.99 & 274649 & 1.37 \\
\hline 27. & Pratapgarh & 867848 & 9.79 & 46046 & 1.78 \\
\hline 28. & Rajsamand & 1156597 & 17.72 & 134620 & 1.58 \\
\hline 29. & Sawai Madhopur & 1335551 & 8.46 & 131714 & 0.80 \\
\hline 30. & Sikar & 2677333 & 14.30 & 211313 & 1.94 \\
\hline 31. & Sirohi & 1036346 & 23.06 & 115625 & 1.79 \\
\hline 32. & Tonk & 1421326 & 12.31 & 224468 & 0.89 \\
\hline 33. & Udaipur & 3068420 & 14.60 & 561541 & 0.88 \\
\hline Total & Rajasthan & 68548437 & 13.47 & 9803283 & 0.97 \\
\hline
\end{tabular}

Source: Transport Department, Govt. of Rajasthan

Fatality risk shows relation between numbers of death occurred due to road accident and population. Average value of fatality risk in Rajasthan is 13.47 in 2011 . Here six categories for fatality risk have been identified for districts of Rajasthan. There are 11 districts in category of 10-12, which is maximum in number and 4 districts having fatality risk more than 18 (Table 6).

Fatality rate is defined as a number of death per thousand vehicles. In Rajasthan average value of fatality rate is 0.97 in year 2012. Districts of Rajasthan have been classified in seven categories of fatality rate. Table 7 presents that there are 11 districts having fatality rate between 0.75 to 1.0 and only district named Churu, having fatality rate more than 2.0.

Table 6: No. of Districts according to Categories of Fatality Risk

\begin{tabular}{|l|l|l|l|}
\hline S. No. & Category & District & $\begin{array}{l}\text { No. } \\
\text { Districts }\end{array}$ \\
\hline 1. & $>10$ & $\begin{array}{l}\text { Banswara, Dungarpur, Jalore, Jhalawar, Karauli } \\
\text { Pratapgarh, Sawai- Madhopur }\end{array}$ & 7 \\
\hline 2. & $10-12$ & $\begin{array}{l}\text { Baran, Barmer, Bharatpur, Churu, Dholpur, Ganganagar, } \\
\text { Hanumangarh, Jaisalmer, Jhunjhunu, Kota, Nagaur }\end{array}$ & 11 \\
\hline 3. & $12-14$ & Tonk, Bikaner & 2 \\
\hline 4. & $14-16$ & $\begin{array}{l}\text { Alwar, Bhilwara, Bundi, Chittorgarh, Jodhpur, Pali } \\
\text { Sikar, Udaipur }\end{array}$ & 8 \\
\hline 5. & $16-18$ & Rajsamand & 1 \\
\hline 6. & $18<$ & Ajmer, Dausa, Jaipur, Sirohi & 4 \\
\hline
\end{tabular}

Table 7: No. of Districts according to categories of Fatality Rate

\begin{tabular}{|l|l|l|l|}
\hline S. No. & Category & District & No. of Districts \\
\hline 1. & $>0.75$ & Ganganagar, Jaipur, Kota & 3 \\
\hline 2. & $0.75-1.0$ & $\begin{array}{l}\text { Ajmer, Banswara, Baran, Bhilwara, Bundi, Chittorgarh, Jhalawar, } \\
\text { Jodhpur, Sawai Madhopur } \\
\text { Tonk, Udaipur }\end{array}$ & 11 \\
\hline 3. & $1.0-1.25$ & $\begin{array}{l}\text { Alwar, Bharatpur, Bikaner, Dungarpur, } \\
\text { Hanumangarh, Jalore, Nagaur }\end{array}$ & 7 \\
\hline 4. & $1.25-1.5$ & Jhunjhunu, Pali & 2 \\
\hline 5. & $1.5-1.75$ & Rajsamand, Karauli & 2 \\
\hline 6. & $1.75-2.0$ & $\begin{array}{l}\text { Barmer, Dausa, Dholpur, Jaisalmer, Pratapgarh } \\
\text { Sikar, Sirohi }\end{array}$ & 7 \\
\hline 7. & $2.0<$ & Churu & 1 \\
\hline
\end{tabular}




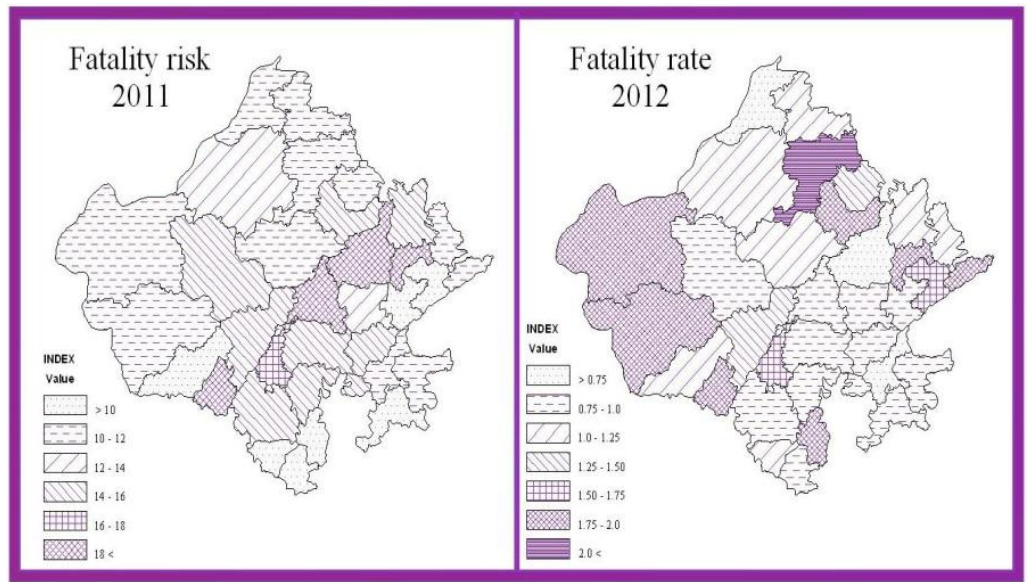

Figure 4: Fatality Risk and Fatality Rate in Districts of Rajasthan

Table 8: Severity Index in Various Districts of Rajasthan (2011 \& 2012)

\begin{tabular}{|c|c|c|c|c|c|c|c|}
\hline S.No. & District & $\begin{array}{l}\text { No. of cases } \\
\text { of road } \\
\text { accidents } \\
(2011)\end{array}$ & $\begin{array}{l}\text { No. of } \\
\text { deaths } \\
(2011)\end{array}$ & $\begin{array}{l}\text { Severity } \\
\text { Index } \\
(2011)\end{array}$ & $\begin{array}{l}\text { No. of cases of } \\
\text { road accidents } \\
(2012)\end{array}$ & $\begin{array}{l}\text { No. of } \\
\text { deaths } \\
(2012)\end{array}$ & $\begin{array}{l}\text { Severity } \\
\text { Index } \\
(2012)\end{array}$ \\
\hline 1. & Ajmer & 1439 & 518 & 35.99 & 1335 & 584 & 43.75 \\
\hline 2. & Alwar & 1192 & 525 & 44.04 & 1243 & 547 & 44.01 \\
\hline 3. & Banswara & 450 & 169 & 37.56 & 430 & 159 & 36.98 \\
\hline 4. & Baran & 498 & 134 & 26.91 & 557 & 149 & 26.75 \\
\hline 5. & Barmer & 509 & 262 & 51.47 & 479 & 258 & 53.86 \\
\hline 6. & Bharatpur & 585 & 285 & 48.71 & 531 & 275 & 51.79 \\
\hline 7. & Bhilwara & 878 & 339 & 38.61 & 889 & 352 & 39.60 \\
\hline 8. & Bikaner & 540 & 321 & 59.44 & 528 & 361 & 68.37 \\
\hline 9. & Bundi & 612 & 156 & 25.49 & 577 & 148 & 25.65 \\
\hline 10. & Chittorgarh & 600 & 219 & 36.5 & 633 & 250 & 39.49 \\
\hline 11. & Churu & 427 & 237 & 55.50 & 415 & 289 & 69.64 \\
\hline 12. & Dausa & 801 & 323 & 40.32 & 667 & 259 & 38.83 \\
\hline 13. & Dholpur & 293 & 138 & 47.09 & 325 & 157 & 48.31 \\
\hline 14. & Dungarpur & 299 & 133 & 44.48 & 326 & 158 & 48.47 \\
\hline 15. & Ganganagar & 434 & 213 & 49.07 & 392 & 209 & 53.32 \\
\hline 16. & Hanumangarh & 321 & 200 & 62.30 & 274 & 149 & 54.38 \\
\hline 17. & Jaipur & 4294 & 1302 & 30.32 & 4084 & 1227 & 30.04 \\
\hline 18. & Jaisalmer & 141 & 70 & 49.64 & 120 & 84 & 70.00 \\
\hline 19. & Jalore & 304 & 128 & 42.11 & 315 & 153 & 48.57 \\
\hline 20. & Jhalawar & 493 & 118 & 23.93 & 529 & 150 & 28.36 \\
\hline 21. & Jhunjhunu & 494 & 233 & 47.16 & 539 & 236 & 43.78 \\
\hline 22. & Jodhpur & 916 & 522 & 56.99 & 966 & 606 & 62.73 \\
\hline 23. & Karauli & 329 & 119 & 36.17 & 336 & 138 & 41.07 \\
\hline 24. & Kota & 946 & 232 & 24.52 & 988 & 214 & 21.66 \\
\hline 25. & Nagaur & 528 & 362 & 68.56 & 488 & 329 & 67.42 \\
\hline 26. & Pali & 790 & 326 & 41.27 & 821 & 377 & 45.92 \\
\hline 27. & Pratapgarh & 222 & 85 & 38.29 & 222 & 82 & 36.94 \\
\hline 28. & Rajsamand & 505 & 205 & 40.59 & 504 & 213 & 42.26 \\
\hline 29. & $\begin{array}{l}\text { Sawai } \\
\text { Madhopur }\end{array}$ & 364 & 113 & 31.04 & 349 & 106 & 30.37 \\
\hline 30. & Sikar & 867 & 383 & 44.17 & 938 & 409 & 43.60 \\
\hline 31. & Sirohi & 403 & 239 & 59.31 & 381 & 207 & 54.33 \\
\hline 32. & Tonk & 532 & 175 & 32.89 & 495 & 199 & 40.20 \\
\hline 33. & Udaipur & 1239 & 448 & 36.16 & 1293 & 494 & 38.21 \\
\hline Total & Rajasthan & 23245 & 9232 & 39.71 & 22969 & 9528 & 41.48 \\
\hline
\end{tabular}

Source : Transport Department, Govt. of Rajasthan

Severity Index measures the seriousness of the accidents and availability of medical facilities in the area. It was increased in 2012 as compared to previous year. There are 20 districts, where severity index slightly increased, but the rate increased highly in Churu and Jaisalmer districts, which was 1.3and 1.4 times respectively. Severity index decreased in 13 districts of Rajasthan from 2011 to 2012 (Table 8). 
Table 9: No. of Districts according to categories of Severity Index (2011)

\begin{tabular}{|l|l|l|l|}
\hline S.No. & Category & District & No. of Districts \\
\hline 1. & $>35$ & Baran, Bundi, Jaipur, Jhalawar, Kota, Sawai Madhopur, Tonk & 7 \\
\hline 2. & $35-40$ & Ajmer, Banswara, Bhilwara, Chittorgarh, Karauli, Pratapgarh, Udaipur & 7 \\
\hline 3. & $40-45$ & Alwar, Dausa, Dungarpur, Jalore, Pali, Rajsamand, Sikar & 7 \\
\hline 4. & $45-50$ & Bharatpur, Dholpur, Ganganagar, Jaisalmer, Jhunjhunu & 5 \\
\hline 5. & $50-55$ & Barmer & 1 \\
\hline 6. & $55<$ & Bikaner, Churu, Hanumangarh, Jodhpur, Nagaur, Sirohi & 5 \\
\hline
\end{tabular}

Table 9 and 10 displays the range of severity index in various districts of Rajasthan during these years. In 2012 the range has been expanded in compared to 2011.

Table 10: No. of Districts according to categories of Severity Index (2012)

\begin{tabular}{|l|l|l|c|}
\hline S.No. & Category & District & No. of Districts \\
\hline 1. & $>30$ & Baran, Bundi, Jhalawar, Kota & 4 \\
\hline 2. & $30-40$ & $\begin{array}{l}\text { Banswara, Bhilwara, Chittorgarh, Dausa, Jaipur } \\
\text { Pratapgarh, Sawai Madhopur, Udaipur }\end{array}$ & 8 \\
\hline 3. & $40-50$ & $\begin{array}{l}\text { Ajmer, Alwar, Jalore, Dholpur, Dungarpur, Jhunjhunu, Karauli. Pali, } \\
\text { Rajsamand, Sikar, Tonk }\end{array}$ & 11 \\
\hline 4. & $50-60$ & Barmer, Bharatpur, Ganganagar, Hanumangarh, Sirohi & 5 \\
\hline 5. & $60-70$ & Bikaner, Churu, Jodhpur, Nagaur & 4 \\
\hline 6. & $70<$ & Jaisalmer & 1 \\
\hline
\end{tabular}

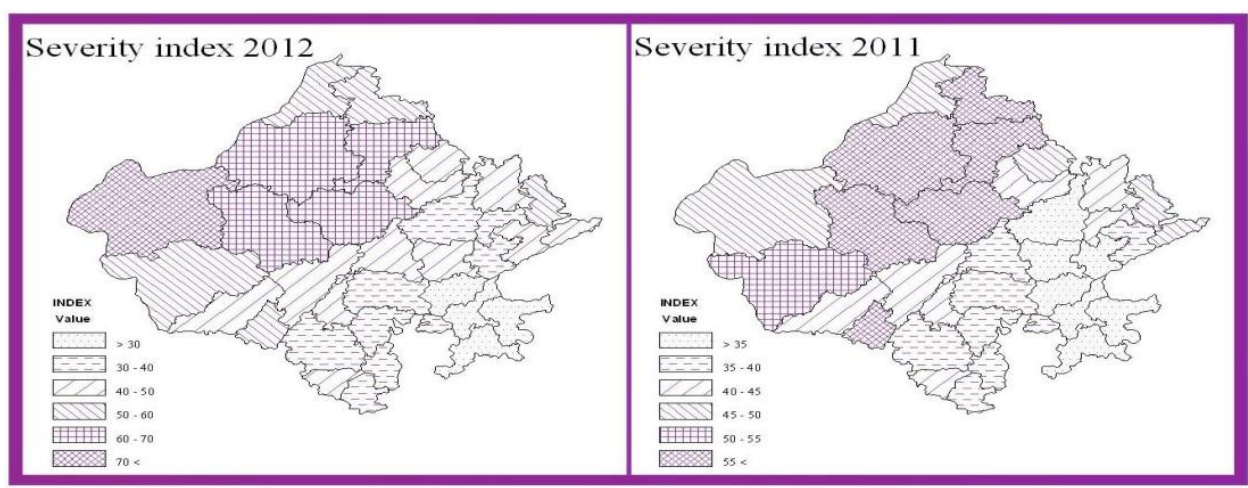

Figure 5: Severity Index of Rajasthan

Table 11: Severity Index in Various National Highways of Rajasthan (2011 \& 2012)

\begin{tabular}{|c|c|c|c|c|c|c|c|}
\hline \multirow[t]{2}{*}{ S. No. } & \multirow{2}{*}{$\begin{array}{l}\text { National } \\
\text { Highway No. }\end{array}$} & \multicolumn{3}{|c|}{2011} & \multicolumn{3}{|c|}{2012} \\
\hline & & $\begin{array}{l}\text { No. of road } \\
\text { accidents }\end{array}$ & $\begin{array}{ll}\begin{array}{l}\text { No. } \\
\text { deaths }\end{array} & \text { of } \\
\end{array}$ & Severity & $\begin{array}{l}\text { No. of road } \\
\text { accidents }\end{array}$ & $\begin{array}{ll}\begin{array}{l}\text { No. } \\
\text { deaths }\end{array} & \text { of } \\
\end{array}$ & Severity \\
\hline 1. & N.H.No.3 & 75 & 31 & 41.33 & 95 & 64 & 67.37 \\
\hline 2. & N.H.No.8 & 1867 & 859 & 46.00 & 1758 & 922 & 52.45 \\
\hline 3. & N.H.No.11 & 1260 & 623 & 49.44 & 1169 & 556 & 47.56 \\
\hline 4. & N.H.No.11(A) & 90 & 32 & 35.56 & 91 & 30 & 33.00 \\
\hline 5. & N.H.No.11(AA) & 3 & 2 & 66.67 & 2 & 1 & 50.00 \\
\hline 6. & N.H.No.11(B) & 105 & 45 & 42.85 & 109 & 35 & 32.11 \\
\hline 7. & N.H.No.12 & 962 & 292 & 30.35 & 839 & 290 & 34.56 \\
\hline 8. & N.H.No.14 & 550 & 262 & 47.64 & 426 & 231 & 54.22 \\
\hline 9. & N.H.No.15 & 392 & 239 & 61.00 & 328 & 243 & 74.09 \\
\hline 10. & N.H.No.65 & 347 & 210 & 60.52 & 377 & 234 & 62.07 \\
\hline 11. & N.H.No.76 & 484 & 238 & 49.17 & 540 & 249 & 46.11 \\
\hline 12. & N.H.No.79 & 421 & 237 & 56.29 & 409 & 217 & 53.06 \\
\hline 13. & N.H.No.79(A) & 54 & 28 & 51.65 & 50 & 22 & 44.00 \\
\hline 14. & N.H.No.89 & 184 & 164 & 89.13 & 200 & 158 & 79.00 \\
\hline 15. & N.H.No.90 & 59 & 17 & 28.81 & 56 & 13 & 23.21 \\
\hline 16. & N.H.No.112 & 191 & 100 & 52.36 & 214 & 154 & 71.96 \\
\hline 17. & N.H.No.113 & 135 & 55 & 40.74 & 162 & 59 & 36.42 \\
\hline 18. & N.H.No.114 & 61 & 51 & 83.61 & 65 & 52 & 80.00 \\
\hline \multirow[t]{2}{*}{19.} & N.H.No.116 & 33 & 8 & 24.24 & 26 & 7 & 26.92 \\
\hline & & 7273 & 3493 & 48.02 & 6916 & 3537 & 51.14 \\
\hline
\end{tabular}

Source: Transport Department, Govt. of Rajasthan

There is marginal increase in severity index on National Highways from 48.02 in 2011 to 51.14 in 2012. But in both years average value of National Highways were comparatively higher than the average value 
of Rajasthan, which was 1.2 times. In 2012 severity index of some National Highways were increased, while declined on others in comparison to 2011 (Table 12).

Table 12: Severity Index and Highways

\begin{tabular}{|l|l|l|l|}
\hline Highways on which Severity Index increased & No. & Highways on which Severity Index decreased \\
\hline N.H.No.3, N.H.No.8, N.H.No.12, & 8 & N.H.No.11, N.H.No.11A, N.H.No.11AA, N.H.No.11B, & 11 \\
N.H.No.14, N.H.No.15, N.H.No.65 & & N.H.No.76, \\
N.H.No.112 & & N.H.No.79, N.H.No.79(A), N.H.No.89 \\
& N.H.No.90, N.H.No.113, N.H.No.114 \\
\hline
\end{tabular}

\section{Conclusion}

Road accidents are a human tragedy. They involve high human suffering and monetary costs in terms of untimely death, injuries and loss of potential income. The present paper provides the magnitude and various dimensions of deaths of road accidental data in districts of Rajasthan. Rajasthan is the largest state of India in geographical perspective. In 2011, Rajasthan has accounted for 5.3\% of total road accidents recorded in India, but it has accounted $6.8 \%$ of total fatalities. Fatality rate, fatality risk and severity index of Rajasthan are high in compared to India. The fatality risk of 13 districts is above than the average of Rajasthan, while 11 districts having fatality rate below the average of Rajasthan. The range of severity index of districts and National Highways of Rajasthan increased in 2012 as compared to previous year.

An attempt has been made to predict situation of fatalities among the districts of Rajasthan. This paper can help policy makers to make accidental management policy and implement remedial in the field of traffic safety.

\section{References}

[1] United Nations Decade of action for road safety 2011-2020. Available from : http:// www.decadeofaction.org.

[2] R.J. Smeed and Jaffocate, Effects of changes in motorization in various countries on the number of road fatalities, Traffic Engineering \& Control, 12(3), 1970, 150-151.

[3] D. Andreassen, Population and registered vehicles data Vs. Road deaths, Accident Analysis \& Prevention, $23(5), 1991,342-351$.

[4] M. Ruikar, National statistics of road traffic accidents in India, Journal of Orthopaedics, Traunatology and Rehabilitation, 6(1), 2013.

[5] D. Mohan, An analysis of road traffic fatalities in Delhi, India, Accident Analysis \& Prevention, 17(1), 1985, 33-45.

[6] D.J. Victor and J. Vasudenan, Factors affecting bus related accidents case study of five corporations in Tamilnadu, HRB, IRC, 4088, 1998, 39-52.

[7] S.B. Bavikar, Road Accidents in Nashik Municipal Corporation Area: A Case Study, Indian Journal of Transport Management, 2319, 1999, 543-555.

[8] S. Chakraborty, Accident Characteristics of roadway Vehicles in Kolkata, ROTRAN, 2, 2001, 6.39-6.45.

[9] S.K. Singh, Road accident analysis: A case study of Patna city, Urban Transport Journal, Vol.2 (2), 2004, 60-75.

[10] R.V. Ponnaluri, Modeling road traffic fatalities in India: Smeed's law, time invariance and regional specificity, International Association of Traffic and Safety Sciences, 36(1), 2012, 75-82.

[11] P. Valli and P.K. Sarkar, Variation in the pattern of road accidents in different states and union territories in India, Proc. $3^{\text {rd }}$ national conf. on Transportation systems studies: Analysis and Policy, 1993, 1X-5 - 1X-9.

[12] R.V. Ponnaluri, Road traffic crashes and risk groups in India: Analysis, interpretations, and prevention strategies, International Association of Traffic and Safety Sciences, 35, 2012, 104-110.

[13] R.K.Singh \& S.K.Suman, Accident Analysis and Prediction of Model on National Highways, International Journal of Advanced Technology in Civil Engineering, 1(2), 2012, 25-30, ISSN: $2231-5721$.

[14] T. Dhār, S.B.S and C.E.G. Justo, Analysis of accidents rates-A case study, Highway research bulletin, Indian road congress, (56), 1981, 1-11.

[15] S. Chandra, Accident Analysis on two lane roads, Highway research bulletin, Highway research Board, IRC, $2004,77-92$.

[16] Road Accidents in India -2011, Transport Research Wing, Ministry of Road Transport and Highways, Government of India, 2012.

[17] National Crimes Record Bureau, Accidental Deaths and Suicides in India, New Delhi, Ministry of Home Affairs, Govt. of India, volume 2001, 2011. 